\title{
Effectiveness of Promotional Schemes in Retail Stores
}

\author{
Chetna, Assistant Professor, Kanya Maha Vidyalaya, Jalandhar, India.
}

ABSTRACT - The flooding of private labels in the apparel market is giving the marketers a run for their money. Client retail players such as Big Bazaar, Shoppers Stop, Westside, Reliance, Spencer's Life Style and many more have revolutionized the functioning of stores today. In the process of evolving a product and service mix, there is a dire need for the retailers focus their efforts on the promotional strategies effectively, so that the product is not a failure. Effective promotional and innovative strategies are the key to success in any organization and will enable the private labels to lure the customer's effectively

Keyword: Promotional, Process, Revolutionized, Strategy

\section{BACKGROUND}

Today, Indian retail advertise is focused by such a large number of set up retailers, since they are searching for new potential market extension. Markets are developing drastically in the previous decades thus consumer loyalty and client dependability have become indispensable points in business advancement plans. Fulfilled and faithful clients are shopping much of the time in their picked retail showcases. Indeed, steadfast clients rehash and increment their buy that assists with expanding deals income of business associations. In this way, consumer loyalty and client experience and unwaveringness are fundamental criticism of an effective retail advertising system in a serious market that makes an incentive for cash for clients. Presently, current hypermarkets and departmental stores just as conventional chaotic outlets have effectively existed together in Indian urban communities with no segregation from the clients yet retail outlets are expanding their piece of the overall industry just as income at the expense and chaotic retail outlets. In Indian metro urban areas and all the more especially customary retail locations are continually drawing in the low and center level salary shoppers both in metros and level 11 and level urban communities. Hypermarket industry is well known worldwide because of the individual buying force and expectation for everyday comforts of individuals. In Indian disorderly retail segment, the staple, fixed, and local or family units shopping stay well down because of shopping comfort yet these retail outlets never tried to comprehend consumer loyalty and no retail showcasing procedure was sent. These hypermarkets gave a similar product as grocery stores however hypermarket, particularly, give person numbers of other commodities and services to customers, such as, car parking facilities, ATM, book stores, Pharmacy, Own inhouse brand, McDonalds, KFC, Pizza hut, The Starbuck and Cafe Coffee Day shops and eateries and strength cafes. Present day retail showcases are uber retail advertise which is the super stores of merchandise or administrations under one rooftop which consolidates general stores, supermarkets and departmental stores where individuals readily shop important products or administrations as for decent variety of item classifications, neighbor horal, national and global brands, value limits or special approach, stopping offices and systems administration of promoting procedure endeavors to fulfill shopping an encounter and high consumer loyalty. Retailing covers the exchange exercises which include in offering products and ventures clients for their family and individual use. Clients' interest for merchandise and enterprises are the regular need where retail industry should focus on offer great assistance just as item quality at sensible cost. The primary capacity y of the retail promoting system is conveyance of better and palatable administrations through proficient and all around arranged and planned administrations inside the retail location and furthermore offices and foundation outside the retail locations. The retailers ought to perform conveyance of value administration to their potential clients other than their ordinary clients. Administration quality is a significant element of consumer loyalty in the retail business

\section{OBJECTIVE}

The Purpose of this Paper Objective are to undertake research to study impact EFFECTIVENESS OF PROMOTION AL SCH ES IN RETAIL STORES.

1. To study the impact of Sales Promotional Offers on customer satisfaction.

2. To assess the attractiveness of the offers to customers.

3. To expose different sales promotion used by retail business.

\section{LIMITATIONS OF THE STUDY}

The study is at the modern retail store. The study is based on reviewing the stores to collect the data 
1. The topographical constraint of the investigation was limited to Jalandhar district.

2. The sample was collected in a limited span of time.

3. The information was not filled properly by the respondents.

4. The data got or the assortment of information is constrained.

\section{REVIEW OF LITERATURE}

Promotion Sales promotion is termed as a "varied compilation of inducement tools typically short-term, prerneditated to encourage more rapidly and/or superior purchase of specific or all consumer goods

Ahern (2008) is of the opinion that sale promotion emerged as a reaction by manufactures markets, and marketing strategies alike to find a short term solution to the problems of excess stock of goods which are available in variables manufacture's warehouse but are not demanded by consumers and organization. Sales promotions are cornparatively easy to apply, and most likely to have considerable effect on the volume of sales

Kotler \& Keller, 2009, in their treatise mention that satisfaction varies from one person to another because it is utility. "One man's meal is another man's venom," an old age stated describing utility; thus highlighting the fact that it is sometimes very difficult to satisfy everyone or to determine satisfaction among group of people

According to Peattie and Peattie, (1994); Lehman and Winer (2002) and Walsh (2000) disputed that sales promotions can be indifferently described as 'extraordinary provisions. It is however disputed that sales promotion persuades accession of amount of product than with no sales promotion.

(Balaghar et al, 2012). Sales promotion refers to every stimulus used by a seller to stimulate the trade and/or consumers to purchase a brand and to persuade the transaction force to repeatedly trade it Sales promotion has been explained as one of the mainly effective system subsequent to advertising and boosts sales extent.

Promotion is an irnportant marketing force that provides extra incentives to achieve Sales and a tool as compared to advertisements and sales force. Promotion is both short term and long term campaign carried.

\section{ELE OF PROMOTION}

Promotions are an externally valuable tool for the marketing of brands. Like all other tools, promotions can make a valuable contribution to rnarketing when they are properly used. Promotions are offered to the customers to get the sales and to increase their market share. The short term promotions are towards grow the sales and the long term sales are towards grow the customer base

\section{WHEN TO USE PROMOTION}

A brands quality is inferior to competition. A brands advertising is not as convincing as cut throat. A new brand is being introduced Deals advancement is a significant segment of a private venture's general promoting methodology, alongside publicizing, advertising, and individual selling. One should include that successful deals advancement expands the essential estimation of an item ternporarily and legitimately animates shopper buying, selling adequacy, or the exertion of the business power. It very well may be utilized to advise, convince, and remind target clients about the business and its advertising blend. Some regular sorts of advancement incorporate examples, coupons, sweepstakes, challenges, in-store shows, public exhibitions, cost off arrangements, premiums, and discounts. Organizations can target deals advancements at three unique crowds: customers, affiliates, furthermore, the associations own business power. Arrangements progression goes as a genuine weapon by giving an extra helper to the planned intrigue gathering to purchase or support one brand over another. It is particularly convincing in goading thing starter and improvised purchases. Appeared differently in relation to various portions of the exhibiting mix (publicizing, presentation, and individual selling), bargains

progression generally speaking chips away at a shorter schedule, uses an undeniably reasonable interest, reestablishes an unquestionable or pal worth, supports a brief arrangement, and contributes significantly to profit. In deciding the relative significance to put on deals advancement in the general showcasing blend, an independent venture ought to consider its advertising spending plan, the phase of the item in its life cycle, the idea of rivalry in the market, the objective of the advancement, and the idea of the item. Instance, deals advancement and regular postal mail are especially appealing choices when the promoting financial plan is restricted, for what it's worth for see independent ventures. What's more, deals advancement can be a powerful apparatus in a profoundly serious market, when the goal is to persuade retailers to convey an item or impact purchasers to choose it over those of contenders. At $\mathrm{g}$ last, deals advancement will in general work best when it is applied to drive things whose highlights can be decided at the purpose of procurement, instead of progressively unpredictable, costly things that may require hands-on exhibit

\section{GROWTH OF SALES PROMOTION}

Sales promotion has grown substantially in recent years. There are several reasons for this dramatic growth in sales promotion $\ln$ the first place, purchasers have acknowledged deals advancement as a component of their purchasing choice models. It gives hesitant leaders a motivating force to settle on decisions by expanding the worth offered by a 
specific brand. Second, the expanding propensity of organizations to concentrate momentary outcomes has helped spike development in deals advancement, which can give a quick lift in deals. Third, the development of PC innovation has empowered producers to get quick criticism on the aftereffects of advancements. Recovery rates for coupons or figures on deals volume can be gotten inside days. At last, an expansion in the size and intensity of retailers has additionally sped the utilization of deals advancement. Numerous business advancements are intended to give advantages to the retailers.

\section{Buyer Promotions}

Buyer deals advancements are directed toward a definitive item users typically singular customers in the nearby market but similar strategies can be utilized to advance items sold by one business to another, for example, PC frameworks, cleaning supplies, and apparatus. Interestingly, exchange deals advancements target affiliates wholesalers and retailers who convey the advertiser's item. Following are portion of the key methods utilized in customer situated deals advancements.

\section{PRICE DEALS}

A purchaser value bargain sets aside the purchaser cash when an item is bought. The principle kinds of value bargains incorporate limits, reward pack arrangements, discounts or refunds, and coupons. Cost bargains are typically planned to support preliminary utilization of another item or line augmentation, to select new purchasers for a develop item, or to persuade existing clients to build their buys, quicken their utilization, or buy various units. Value bargains work most adequately when cost is the customer's preeminent basis or when brand dedication is low. Purchasers may find out about value limits either at the retail location or through promoting. At the retail location, value decreases might be posted on the bundle, on signs close to the item, or in customer facing façade windows. Numerous kinds of commercials can be utilized to advise purchasers of up and corning limits, including fliers and paper and TV advertisements. Values are particularly regular in the food business, where nearby stores week after week specials.

For example, a producer may "pre-value" an item and afterward persuade the retailer to take an interest in this transient markdown through additional impetuses. For value decrease methodologies to be powerful, they should have the help of all merchants in the channel. Existing clients see limits as remunerations and frequently react by purchasing in bigger amounts. Value limits alone, be that as it may, for the most part don't instigate first time purchasers.

Another kind of value bargain is the reward pack or joined pack. At the point when a reward pack is offered, an additional measure of the item is free when a standard size of the item is purchased at the normal cost. This strategy is routinely utilized in the promoting of cleaning items, food, and wellbeing and magnificence helps to present another or bigger size.

Coupons are lawful declarations offered by makers and retailers. They award indicated reserve funds on chosen items when introduced for reclamation at the purpose of procurement. Producers continue the expense of publicizing and disseminating their coupons, reclaiming their assumed estimations, and paying retailers dealing with charge. Retailers who offer twofold or triple the measure of the coupon shoulder the additional expense. Retailers who offer their own coupons acquire the complete expense, including paying the assumed worth. Along these lines, retail coupons are identical to a penny off arrangement.

\section{Challenges/SWEEPSTAKES}

The primary contrast among challenges and sweepstakes is that challenges expect participants to play out an assign me or show an expertise that is decided so as to be considered a victor, while sweepstakes include an irregular drawing or chance challenge that could conceivably have a section prerequisite. At once, challenges were all the more ordinarily utilized as deals advancements, for the most part because of lawful limitations on betting that numerous advertisers dreaded may apply to sweepstakes.

\section{PREMIUMS}

A premium is unmistakable pay that is given as impetus for plying out a specific demonstration as a rule purchasing an item. The premium might be given for nothing, or might be offered to customers at an essentially diminished cost. A few instances of premiums incorporate accepting a prize in an oat box or a free digging tool for exisiting the excellent opening of a horne improvement shop. Motivating forces that are given for nothing at the hour of procurement are called direct premiums. These offers give moment delight, in addition to there is no disarray about returning coupons or box tops, or sparing standardized tags or confirmations of procurement. Mail premiums, not at all like direct premiums, require the client to ply out some demonstration so as to acquire a premium through bring mail back. A model may be a constrained release toy vehicle offered by an advertiser in return for at least one verifications of-procurement and an installment taking care of the expense of the thing in addition to taking care of. The premium is as yet important to the customer since they can't promptly purchase the thing for a similar sum.

A last type of test conveyance many claim to fame kinds of examining. For example, a few organizations spend significant time in pressing examples together for conveyance to homogeneous customer gatherings, for example, love birds, inexperienced parents, understudies, or voyagers. Such bundles might be conveyed at emergency 
clinics, inns, or quarters and incorporate various kinds of items.

A trade sales promotion is earmark at resellers, wholesalers and retailers who distribute manufacturers' products to the ultimate consumers. The objectives of sales promotions focus at the trade are different from those directed at consumers. In general, trade sales promotions hope to achieve four goals:

1. Develop in-store merchandising, as strong support at the retail store level is the key to closing the loop between the customer and the sale.

2. Control inventory by increasing or reducing inventory size thus helping to get rid of seasonal peaks and valleys.

3. Enlarge or enhance distribution by opening up new sales areas (trade promotions are also sometimes used to distribute a new proportions of the product).

4. Create excitement about the product among those responsible for selling it. Some of the most common structure of trade promotions describe below include point-of- purchase displays, trade shows, sales meetings, sales event, push money, deal loaders, and promotional consideration.

The last kind of purchasing remittance is a free product recompense. For this situation, the maker offers a specific measure of item to wholesalers or retailers at no expense on the off chance that they buy an expressed measure of the equivalent or an alternate item. The remittance appears as free product as opposed to cash.

\section{Promoting Allowances}

A publicizing recompense is a profit paid by an advertiser to an affiliate for promoting their item. The hard cash must be utilized to buy impart for instance, to print flyers or run promotions in a locale paper. In any case, some affiliates exploit the framework, such huge numbers of producers require check. A showcase recompense is the last type of exchange limited time stipend. A few makers pay retailers extra to feature their presentation from the numerous accessible consistently. The installment can appear as money or products. Retailers must outfit comprised confirmation of consistence with the details of the agreement before they are paid. Retailers are well on the way to choose shows that yield high volume and are anything but difficult to gather.

The advancement can genuinely play out its capacity of quickening preliminary and acquisition of a brand whose worth has not yet been completely settled in the psyches everything being equal. Albeit great promoting on another brand will convince numerous buyers to attempt the brand, it isn't probably going to convince each consistent possibility to make prompt money. In spite of the fact that the promoting doesn't rapidly move to activity require an additional motivating force, for example, a free example or coupon or some other gadget that builds the estimation of the brand, or brings down its cost, to where the possibility chooses to get it. On the off chance that the item is of acceptable quality, advancement consequently assists with building up its worth rapidly in the psyches of more individuals

\section{RESEARCH OBJECTIVES}

This marketing research aims to study:

1. To sale promotion means price offer, discounter, End of the season, etc customer towards Retail Stores.

2. To measure the sale promotion level of overall shopping experience at stores.

\section{RESEARCH METHODOLOGY}

MEANING: The systematic method consisting of expressing the problem, workout a hypothesis, collecting the facts or data, examining the facts and reaching certain either in the form of solution towards the concerned problem or in certain elicitation for some theoretical reflection

\section{INTRODUCTION}

This report throws light on the satisfaction level of customer at retail stores. For completion of this report a survey was conducted and for fulfillment of questionnaire, a sample size of 50 was selected. Different researchers have defined research in various ways due to its wide scope.

\section{RESEARCH DESIGN}

- Descriptive research design

- Casual research design

1) Descriptive RESEARCH Descriptive research emphasizes on explaining the phenomenon by providing factual and accurate information. It is very suitable for research in education. It is also known as statistical research, describes data and characteristics about the population or phenomenon being studied. However, it does not answer quest ion about e.g. how/when/why the characteristics occurred, which is done systematic research

Here, I am taking DESCRIPTIVE RESEARCH as my research design because it helps me to describe my topic with more details.

\section{SOURCE OF DATA}

I) PRIMARY DATA: The data collected by the researcher himself for finding the solution of a particular problem or situation, is known as primary data. This type of data is characterized by its originality as it is freshly collected.

\section{DATA COLLECTON INSTRUMENT:}

There are some data collection instruments which are as under: 
- Questionnaire

- Checklist

- Distribution

- Interview

- Observation

- Records

- Experimental Approach

\section{FINDING}

Brand mindfulness, Brand nature, brand agreeability, Sales advancement and showcasing correspondence in this investigation. In principle, if an individual is new to a brand, the data they get from the advertising correspondence and ought to impact their mentality towards the brand.

\section{CONCLUSION}

- Promotional offers play an foremost role to increase the sales in short time

- The customer buying pattern has changed with the introduction of new sale schemes.

- The foot fall has increased at stores customers are expecting to get their things o reasonable way.

- Today and tomorrow marketing managers really do not have the choice whether or not to use sales promotion but only whether to use these valuable tools imperfectly or skillfully

It is the inferred that business advancement is essential to improve the deals of the organization and to arrive at new clients. Every single association ought to have a decent vital arrangement for their advancement to withstand in the market with tremendous rivalry. The limits and dependability program in the organization will improve the deals by pulling in new clients. The best deals advancement will assist the organization with fulfilling the hierarchical targets. The business advancement is must to improve their deals in each association. The deals is checked dependent on the limited time exercises rehearsed by the association, the organization ought to have better special exercises rehearsed in the association to appraise the deals.

\section{BIBLIOGRAPHY}

[1] The research dealt exclusively with secondary literature, newspaper, text books journals.

[2] Babakus E., Tat P. and Cunningham W. (I9SS), "Coupon Redemption: A Motivation Perspective," Journal of Consumer Marketing, 5 (2), 37-44.

[3] Blattbarg, R. and Neslin, S. ( 1990), Sales Promotion: Concepts, Methods, and Strategies. NJ: Prentice Hall.

[4] Davis S. J., Inman J. and McAlister L. (1992), "Promotion has a Negative Effect on Brand Evaluations - Or Does it?", Journal of Marketing Research, 29 ( I ), 143- 149.
[5] Gupta, Sunil ( 1988), "Impact of Sales Promotions on When, What, and How Much to Bu y," Journal of Marketing Research, 25 (November).

[6] Kotler, Philip \& Armstrong, Gary (2006), Principles of Marketing. Pearson Education Inc, Upper Saddle River, New Jerse y.

[7] Signe, S.P., K.L. Ailawadi and N.D. Beauchamp (2005), "Consumer and Retailer Promotions: Who 1s Better Off? “, J. Retailing, 85(4), 449-460

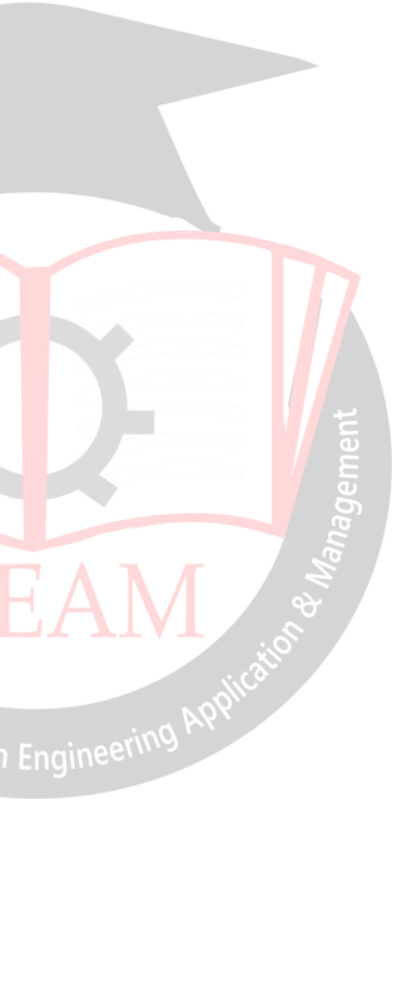

